\title{
EMPLOYEE STOCK OWNERSHIP AS STRATEGY TO IMPROVE EMPLOYEE PERFORMANCE (CASE OF BANK SYARIAH MANDIRI YOGYAKARTA)
}

\author{
Aulia Rahmadanti Chisaan ${ }^{a}$ \\ Muhammad Zakiy \\ ${ }^{a, b}$ Muamalat (Islamic Banking and Islamic Economics), Faculty of Islamic Religion, University \\ of Muhammadiyah Yogyakarta \\ Email: aulia chisaan@yahoo.com; muhammad.zakiy@fai.umy.ac.id ${ }^{\mathrm{b}}$
}

\section{ARTICLE HISTORY}

Received:

16 August 2019

Revised:

16 May 2020

Accepted:

24 May 2020

Online available:

30 June 2020

Keywords:

Bank Syariah Mandiri,

Cade Study,

Employee Performance,

Employee Stock,

Strategy

*Correspondence:

Name:

Muhammad Zakiy

E-mail:

muhammad.zakiy@fai.umy.ac.id

\section{ABSTRACT}

The purpose of this study is to analyze the influence of Employee Stock Ownership Program (ESOP) phenomena on employee performance, which can be used as an alternative in conducting a strategic issue by the management of sharia banks and also as an addition to the science horizon through the scientific work that researchers examine. The results of this study can then be arranged as a strategic target related to company resources and competitiveness in increasing competition in the financial industry. This research uses descriptive qualitative research using convenience sampling as a technique of collecting data from a total of 13 informants who are employees of PT Bank Syariah Mandiri Area Yogyakarta and its branch offices with different field positions using interviews as the primary data, with questionnaires and observations as supporting data. The results of this study showed that $31 \%$ of informants knew details about the capital market and information about Employee Stock Ownership Program, 61\% knew partially, and 8\% did not know. The majority of informants (employees) as much as $69 \%$ were positively enthusiastic about the enactment of the Employee Stock Ownership Program, and 54\% of the total informants expressed interest and wanted to own shares of the company where they worked. The researcher also found data that was of a view and mass perspective as much as $77 \%$ Employee Stock Ownership Program had a positive effect on employee performance. 


\section{INTRODUCTION}

Widespread foreign domination of the companies ownership status in Indonesia is still an important evaluation considering that as many as $67 \%$ of shares in the capital market, including more than $50 \%$ of banking shares, have been controlled by foreign investors, reciprocally when viewed from the aspect of job offers, as well as dependence on foreign capital, this can lead to weakening job opportunities (Santosa, 2018). One of the reasons behind the weak opportunities is because the recruitment of employees is apparently not in accordance with the competency requirements specified by the company. Production relations become undemocratic and more unequal at the same time; the undemocratic company will affect employee performance to be less conducive. Moreover, in a case of problemsolving when making decisions in companies and controlling system by foreign is also increasingly beyond the reach of work participation because it is done by the owners of capital who are far away abroad so that it becomes less effective and conducive.

The phenomenon is the cause of the lack of welfare of workers in Indonesia. Even though the most crucial asset in a company or organization is human resources, having a good quality of human resources will increase the value of the company. HR is one of the assets that are intangible or cannot be measured monetarily (Purnawanto, 2010). One of the indicators in measuring the quality is through performance, so that performance is an essential factor for organizational sustainability. Performance is an action result achieved by an individual or a group of people in a company according to their authority and responsibility as an effort to achieve the goals of the institution, and does not conflict with morals, ethics, and does not violate the law (Basri \& Rivai, 2005). Performance appraisal is a measurement of the contributions of each individual in the agency when carrying out business activities. An important point of performance appraisal is from determining how much the level of contribution of each individual in the company where they work or the performance that is expressed, but the dominance of foreign ownership of companies in Indonesia has become the forerunner to the minimum contribution of each employee in decision making and company ownership.

Based on this issue, the researcher intends to study the Employee Stock Ownership Program at Islamic Financial Institutions that will plan an Initial Public Offering (IPO). The object of the research will be conducted at PT Bank Syariah Mandiri Area Yogyakarta as research on the application of the Employee Stock Ownership Program in companies that are planning an initial public offering. This program has not been widely implemented in most companies, and a few of them used it as an alternative program to improve employee performance, at the end of this research hopefully the companies that are used as researchers as research objects will apply for the Employee Stock Ownership Program. Therefore researches on the Employee Stock Ownership Program is an urgency that needs to be reviewed 
on an ongoing basis to analyze the extent of the Employee Stock Ownership Program phenomenon in Indonesia.

Many people are still doubtful about the performance of employees who are considered less competent as employees of Islamic financial institutions, and this is indicated because of the incompatibility of human resource competencies with the job market (Asnaini, 2008). Likewise, it was also revealed that there was an imbalance of adequate and qualified human resources. It is mainly because of seeing the discipline of human resources, causing the slow development of Islamic banks in the community (Fitria, 2014). Hopefully, this program can improve employee performance, increase organizational commitment, the application of economic democracy in accordance with Islamic banking principles, and later followed by an increase in the company's image as well.

In connection with the above facts the Employee Stock Ownership Program can improve employee performance because through the Employee Stock Ownership Program, employees can contribute in making corporate decisions, so that it becomes an added value for the employees themselves and helps in developing the company's value. In addition, employees will also have a sense of ownership of the company so that they are eager to work in their own company. The implementation of the stock program for workers is arguably an investment medium for employees who can prosper employees and increase the productivity of the country's economy. The Employee Stock Ownership Program can also be prevention and other solution in overcoming company crises in the form of dismissal of employees so as not to reduce the value of employee performance.

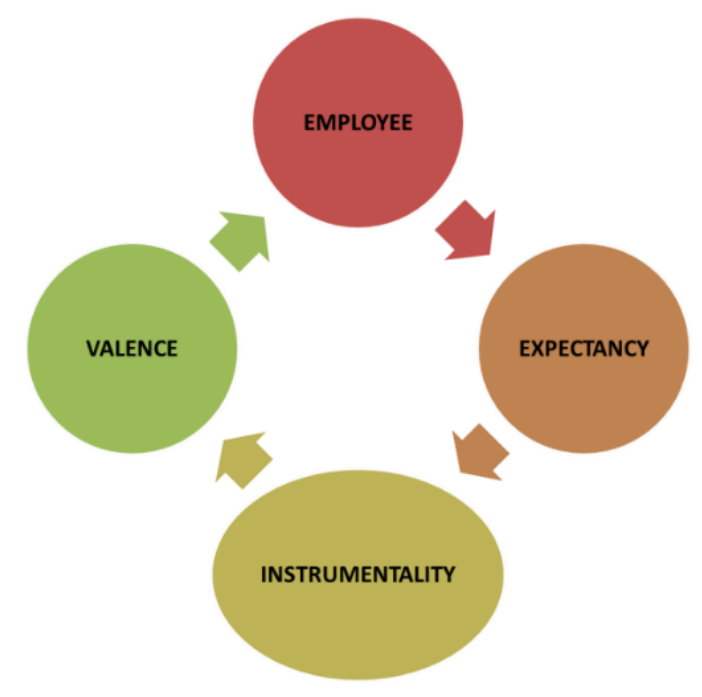

Figure 1. Vroom's Path Expectancy Theory

Source: Author Research Data

Application of Employee Stock Ownership Program has not yet been applied to PT Bank Syariah Mandiri (Bank Syariah Mandiri, 2018). However, researchers will 
use a projective technique (by assuming) that is by analyzing the extent of the effect of the Employee Stock Ownership Program on the level of employee performance at the institution. Employee performance will be seen according to indicators of work skills, creativity, discipline, cooperation, and responsibility. The assumption built by researchers is that if an employee who owns shares in the company where he works, then the employee's performance will be more leverage than employees who do not have shares in the company. It is because the high and low performance of employees will affect the ups and downs of shares in the company, which will affect the welfare of employees. The purpose of this study is to determine and analyze the Employee Stock Ownership Program can influence in improving employee performance at PT Bank Syariah Mandiri Yogyakarta.

\section{LITERATURE REVIEW}

Setyaningrum (2012) mentions agency theory based on the contractual relationship between members in the company, with the principal (principal) and agent (agent) as the main actors. The principal is the party that gives the mandate to the agent to act on behalf of the principal, while the agent is the party who is given the mandate by the principal to run the company. Hull \& Dawar (2014) describing agency conflict, agency theory explains that agency relationships arise when one or more people (principals) employ other people (agents) to provide services and then delegate decision-making authority to agents. The principal or company owner hands over the company's management to management. The manager as the authorized party for the company's activities and must provide financial reports will tend to report something that maximizes the utility and sacrifice of the interests of shareholders. As a company manager, the manager will know more internal information and the prospects of the company versus the owner (shareholder).

Countries with developing economies according to Wiseman et al,. ( 2012) have a corporate governance system and create informal mechanisms to deal with specific 'weak governance' environments, all of which are characterized by conflicts between controlling shareholders and minority shareholders in the company. Known as the 'principal-principal model', recognizing the potential for conflict between actors requires a different solution than one that assumes a common interest among actors where maximizing shareholder wealth is the most important, if not the only relevant goal. Based on the statement of problems of ownership of shares by employees to improve employee performance is very important to be reviewed, especially for banks that have the potential to have agent problems.

The expectancy theory by Vroom (1964) in Anatan (2010) defines motivation in the performance that people will be motivated to do certain things to achieve goals if they believe that their actions will lead to the achievement of a goal. Vroom's (1964) expansion theory in Saktiyanto et al. (2013) assumes that each individual believes that when the individual behaves in a particular manner, he will 
undoubtedly get certain things, too, then special actions will get extraordinary results. That each outcome will, of course, be related to personal perceptions of how difficult it is to achieve an outcome, then the effort will produce an achievement. That every result will be valuable, be an attraction for anyone, then everyone wants to produce the expected value.

\section{Relationship of ESOP to Employee Performance}

Performance is an action result achieved by an individual or a group of people in a company that is in accordance with their authority and responsibilities as an effort to achieve the goals of the institution, and does not conflict with morals, ethics, and does not violate the law (Basri \& Rivai, 2005). Performance appraisal is a measurement of the contributions of each individual in the agency when carrying out business activities. An essential point of performance appraisal is the determination of the level of participation of each individual to the company where they work or the performance expressed in the completion of the tasks for which he is responsible.

The performance appraisal method uses the company's internal analysis system as a whole pre-condition to identify strategic issues that management must review and then compile them into strategic targets relating to company resources and competitiveness for exceeding competition in the industry (Marietta \& Sampurno, 2013). Meanwhile, according to Sabitah \& Susilo (2017), another performance evaluation method that is 360-degree feedback is a multi-source assessment through evaluation from superiors, colleagues, subordinates, and selfassessment. Evaluation of soft competence in companies is measured by a 360degree feedback scoring system because the results of assessments from various assessors affect the objectivity of the assessment.

The implementation of the Employee Stock Ownership Program (ESOP) in a company has a variety of objectives, one of which is vital as its goal to increase the sense of ownership of employees so that in the future it will improve employee performance and company performance Hartono \& Wibowo (2014). The Employee Stock Ownership Program (ESOP) can have a proper character and value in an organized performance, and primarily when employees perform in a team, of course, this is influenced by some values, traditions, and beliefs (Landau et al., 2007). According to Brown, Minson, O'Connell, \& Ramsay (2011), this program, which measures the value of shares or ownership, is manifested in money incentives as productivity is a powerful incentive and motivator in actively increasing employee performance participation. ESOP can be regarded as an award or compensation for the welfare of employees both employees individually and generally in the company.

Saptarina et al. (2002) define "the Employee Stock Ownership Program (ESOP) is an employee stock ownership program for the shares of the company." The technical implementation consists of four classifications, namely the provision of 
Stock Grants on companies to employees selected as compensation or bonus, the purchase of shares by employees on conditions that benefit workers (Direct Employee Stock Purchase Plans), the purchase option program by employees on a certain number of shares sold by the company in a specified period and transaction period (Stock Optional Plans). Finally, the Stock Ownership Plans designed in the form of fund management (Saptarina et al., 2002).

Almisri in Hasanudin \& Mubarok (2012) argues that in companies that have not implemented ESOP cooperation between the capital owners (shahib al-mal) and employees (mudarib) is another form of the syirkah-mudharabah concept. Generally, syirkah is implemented aimed at achieving the welfare of the person involved, and syirkah-mudharabah aims higher than that, it is to obtain the public benefit. The syirkah contract is permitted according to the scholars of figh. If the provisions of the syirkah-mudharabah are appropriately implemented, this contract will give a good impression to the workforce. Employees will feel satisfied because they benefit from the results of the collaboration, and this will encourage them to work harder because when business results increase, they will also get more income.

Researchers conducted various studies on several literature reviews of previous research results, including Trébucq (2004) in the results of his empirical study entitled The Effect of ESOPs on Performance and Risk: Evidence From France. The research shows that firm performance is indeed related to ESOP in France companies. Freeman (2007) also conveys the relationship between ESOP adoption and firm performance in his study, The Effects of ESOP Adoption and Employee Ownership: Thirty years of Research and Experience on ESOP. The result shows employee ownership is positive and credible. The research shows Job satisfaction is positively correlated with ESOP adoption, ESOP adoption results in post-adoption company performance that is better than pre-adoption company performance. Based on a study entitled Employee Stock Option Plan and Firm Performance: a Quantile Regression Approach by Ray (2016), the empirical results illustrate the positive impact of ESOPs on company performance at the maximum quantile level. Similar evident shows from empirical findings of a lower level of quantile ROE, the effect of a positive ESOP on company performance, the results reveal that ESOP or total compensation is positive at most quantile levels of market performance. Zhu et al. (2013) also conducted a result on their empirical study, Employee Stock Ownership Plans, and Their Effect on Productivity: A Case of Huawei. The study shows that ESOP is a good factor to enhance employee performance. 


\section{RESEARCH METHODS}

\section{Research Model}
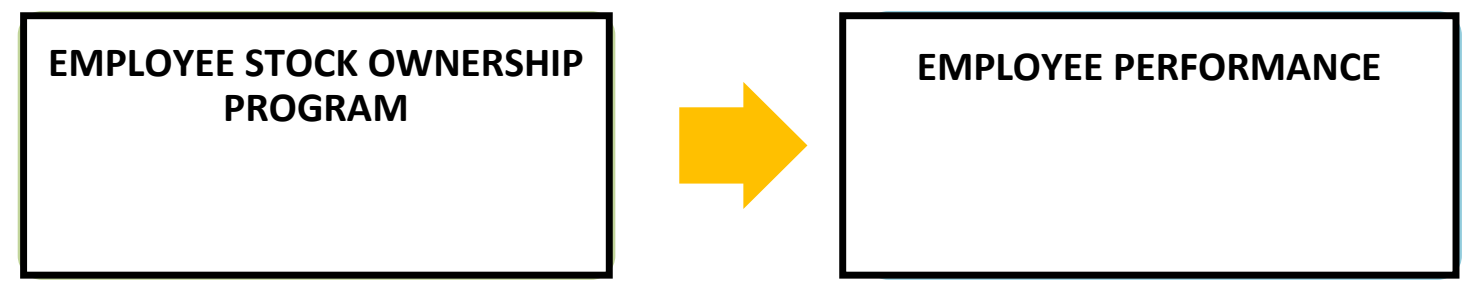

Source:Author Research Data

Figure 2. Research Model

The Employee Stock Ownership Program can be expected to affect employee performance if researchers see the effect of ESOP issue responses, which are described in the form of interviews and questionnaires and observations on employee performance appraisal according to indicators of work skills, creativity, discipline, collaboration, and responsibility.

The study examined is descriptive qualitative research, with a projective technique (presupposition), which is the type of research in the form of exposure to symptoms or phenomena illustrated from the data taken, so that connoisseurs of this study will feel the euphoria of the depiction of phenomena as the researchers do (Moleong, 2017). The research object was located at PT Bank Syariah Mandiri Area Yogyakarta along with three branch offices. The sampling technique that the researchers used for this research are the non-probability sampling technique, which means the sampling technique is not given to this sample the same opportunity for each element or member of this population to be selected to become a sample (Sugiyono, 2015). Researchers, in this case, chose the sampling method based on the ease of data acquisition criteria, namely convenience sampling in the form of 13 employees as informants with different field positions, consisting of one Cash Outlet Manager referred to as informant 1, one Banking Operation Support Manager, referred to as informant 2, two Customer Services referred to as informant 3 and informant 8, one Pawning Officer referred to as informant 4, one Teller referred to as informant 5, one Head of Area Human Resources referred to as informant 6, one Area Service Officer referred to as informant 7, one Micro Banking Manager referred to as informant 9, one Branch Manager referred to as informant 10, and three Area Business Segment Managers referred to as informant 11, informant 12, and informant 13.

The data used as material for this study consisted of primary data in the form of answers to research sample sources obtained from in-depth interviews which were used as the main data source, then assisted with supporting data using observations, questionnaires, and other secondary data namely the company's 
audited annual financial statements for 2017 and 2018. The data validity technique used is the triangulation method, this is also a procession of comparison and checking the suitability of data sources obtained for the first time in the data collection process by collecting different data in the subsequent or final collection process (Moleong, 2017). In the data validity technique, the first part of the qualitative research method in the data validation process, accustomed to observing observations or referred to as the persistence of the observer and intended to find elements and characteristics in a situation relevant to the problem or phenomenon sought in research. Then, it will be investigated with detailed and also continuous observations about the prominent factors, and then it is analyzed to the point of understanding and temporary conclusions (Moleong, 2017).

Patton in Poerwandari (2001) states that data analysis is a process for organizing data sequences, then assembled it in a series of patterns, categories, and one primary sequence. Analysis of the data used in descriptive qualitative research is as follows:

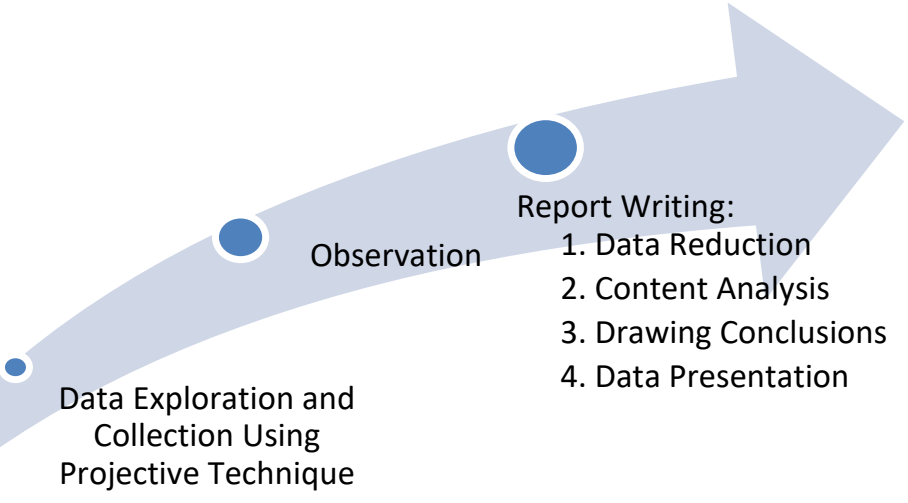

Figure 3. Descriptive-Qualitative Data Analysis Technique Source: Author Research Data

\section{Data Reduction}

Data reduction is the process of researchers in terms of weeding the data to get the core research problem from research results that are still of raw value to be processed into concrete data. Researchers do data processing and filtering so that in writing to the research results, researchers have reduced abstract data collected and then compiled it into credible data based on the results of data collection that matches the focus of the research.

\section{Content Analysis}

Data analysis can be done after getting the results of primary and secondary data from the research object. The principal or primary research data was collected from the interviews and questionnaires for researchers on research subjects, in this case, employees at PT Bank Syariah Mandiri Area Yogyakarta and its branch offices, for secondary data from research objects, taken from observations related to the 
assessment of aspects observation and documentation of institutional data; and easier to compile the essence of research elaborated on this method.

\section{Drawing Conclusions}

The conclusion was drawn by the researcher after conducting the data reduction stage and compiling it in the analysis content. Researchers carry out the refinement stage of the essence of scientific work with the main verification points at the focus of the research at the stage of concluding. The process of data display presented at this stage is the result of reduction and processing of data that has been comprehensively analyzed so that later writers will be better able to understand from existing data and end with the presentation of concrete data in the results of research.

\section{RESULTS AND ANALYSIS}

From this interview the researcher took 4 essences which were used as indicators of the researcher in determining whether or not the ESOP program had a positive effect on employee performance, first is capital market knowledge and ESOP, second, ESOP interest needs to be implemented at Bank Syariah Mandiri, third, the desire to own company shares in where they work, and fourth, the influence of the ESOP on individual performance.

The definition of ESOP as it is known is the employee's stock ownership program for the shares of the company where the employee works (Saptarina et al., 2002), the existence of share ownership by the employee is intended to appreciate the employee so that the employee can continue to develop themselves in their business as meeting their needs. The ESOP program is actually useful for employees in meeting their needs, such as dividends generated can later be used as venture capital, additional family livelihoods, and so on as meeting needs, with a note if it is run properly and accordingly.

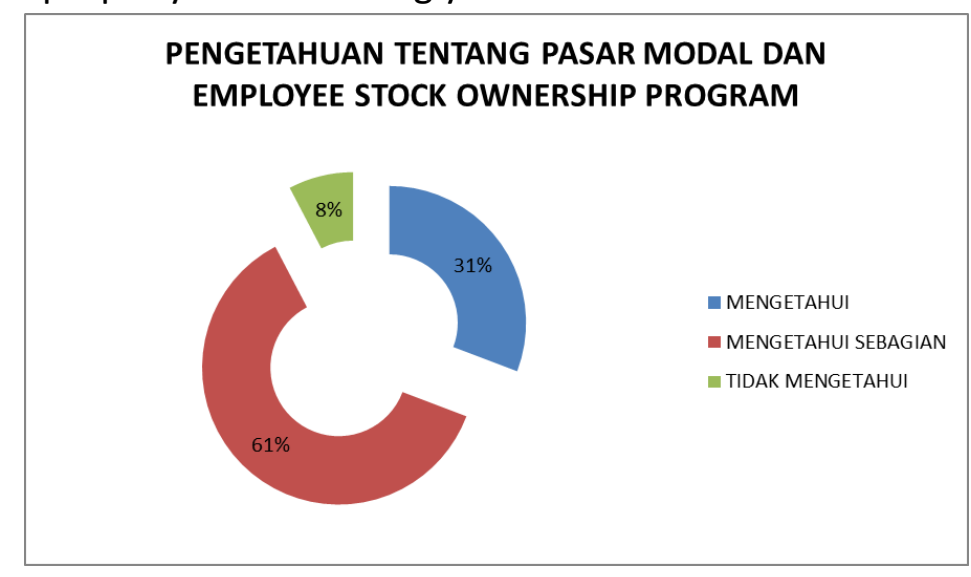

Information:

Blue: well knew Red: knew partialy Green: not knew

Figure 4. Survey Results of Informants' Knowledge on Research Issues Source: Bank Syariah Mandiri 2019 Processed Data 
As for the matter of capital market knowledge and ESOP, from the interview results, researchers found that $31 \%$ or four of them total informants knew enough details about the capital market and employee stock ownership program (ESOP). Other informants by $61 \%$ or eight of them knew partially. At the same time, a nominal $8 \%$ of the total informants or one of them did not know the details related to the capital market or ESOP in general. Researchers in this case also found that one among those in the category of knowing said that a positive ESOP would be applied at PT Bank Syariah Mandiri in 2020, and the company would use the share allocation with a bonus calculation or not an initial purchase. In accordance with the statement and description of the data above, it can be explained that PT Bank Syariah Mandiri is making preparations slowly but surely for the implementation of the employee stock ownership program and over time the company has provided program information even though it is still in the form of verbal sounding through scheduled meetings scheduled and there is $8 \%$ of miss information about the program's issue.

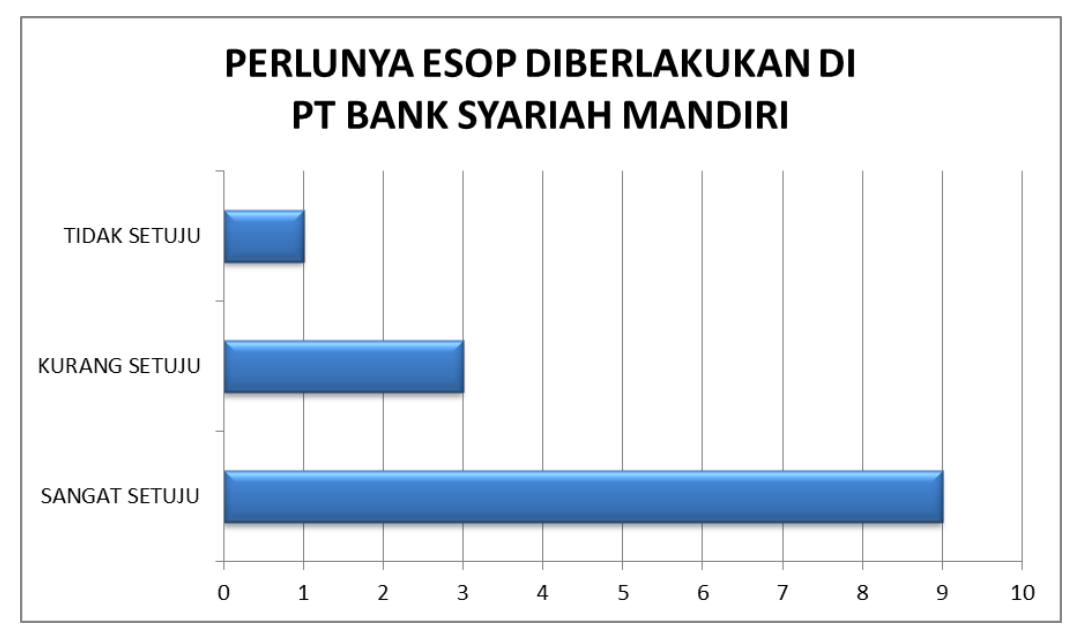

Figure 5. Informant Response Data About the Need for ESOP Implemented at PT Bank Syariah Mandiri Source: Bank Syariah Mandiri 2019 Processed Data

For the matter of ESOP approval, it needs to be implemented at Bank Syariah Mandiri. From the interview results, researchers found that although not yet fully informed about the ESOP details and technical issues, the majority of $69 \%$ of the informants expressed interest in the existence of this ESOP program, they stated that they needed and agreed to implement the program. However, some do not approve or even disagree with the existence of this program. Researchers found 9 out of 13 informants interviewed said they strongly agreed with the implementation of the ESOP program at Bank Syariah Mandiri. At the same time, three of them expressed some disagreement, and the rest did not agree with the existence and implementation of this program. 


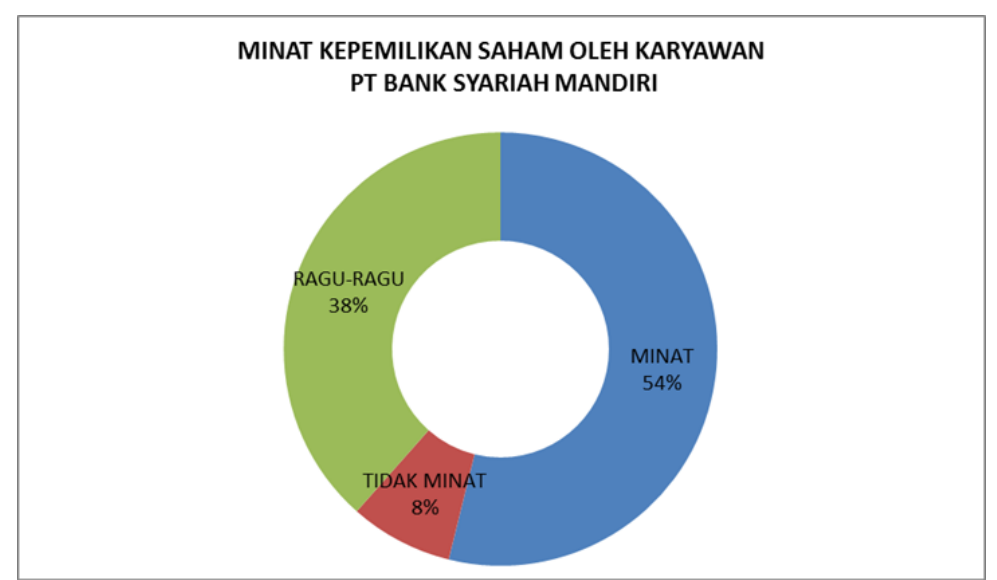

Figure 4. Interest of Employees on Possessing Stock of Bank Syariah Mandiri Source: Bank Syariah Mandiri 2019 Processed Data

As for the desire to be interested in owning shares of Bank Syariah Mandiri, researchers found that most of the informants were interested in and wanted to own shares in Bank Syariah Mandiri, as many as $54 \%$ or seven informants from total informants responded to their interest and wanted to own shares of Bank Syariah Mandiri even by buying these shares in order investing, $38 \%$ or five of them gave hesitant responses, and $8 \%$ or one of them had no interest and did not want to own shares in Bank Syariah Mandiri. Two informants in the category of strongly agree about the implementation of the ESOP in their place of work from the results of the interview the researchers found that the informants were still constrained in financial matters, thereby reducing their interest in holding Bank Syariah Mandiri shares in the near future.

The fact is, up to this moment, the implementation of the ESOP has not been very well known. Especially at Bank Syariah Mandiri (BSM), one of the largest sharia banks in Indonesia is still unable to implement this ESOP program. The researchers found those in the interview process of the informants, where indeed the discussion about the application or realization of the ESOP program was still limited to discourse in the future. Moreover, the researchers also assessed that some of them still did not know the ins and outs of the ESOP program more deeply, even though their notes are as a player who runs Islamic banking. It should also be noted that the ESOP program is still very new in the environment of Islamic banking, especially at Bank Syariah Mandiri, so that it is not a meaningful discourse of Islamic banking in developing capital markets. Moreover, it is not fully socialized in Islamic banking. It affects the inequal level of knowledge about the ESOP program. Whether in the future, the ESOP program will be implemented and implemented in an Islamic banking system, many things must still be considered.

In this case, many researchers found two matters in the field, first, related to the level of knowledge of Bank Syariah Mandiri employees, most did not yet know 
extensively and deeply about the investment stock program and the capital market world, especially about the ESOP which by researchers, in this case, became the main theme of the study. Researchers also get information that Bank Syariah Mandiri will start enacting ESOP in 2020. Until now, Bank Syariah Mandiri is trying to strengthen its initial public offering, and prepare other factors to prepare themselves to develop investment stocks and capital markets to go public, namely by how to implement ESOP in the working environment of Bank Syariah Mandiri. Second, to implement the ESOP within the Bank Syariah Mandiri itself as one of the Islamic banks, Bank Syariah Mandiri needs to convince its employees both by providing information as broad as possible about the world of capital markets, stock investments, especially ESOPs in all layers both top to bottom. Because many researchers also found in the field, even the majority were interested and wanted the implementation of this ESOP program in Bank Syariah Mandiri for various reasons. Still, not all of them understand and have enough knowledge related to this ESOP program, so there were also some who were still in doubt and still considering, even some are not interested in this program.

Bank Syariah Mandiri needs to improve the quality of its employees by holding qualifications and professionalization of employees so that employees can work in accordance with the full qualifications and professionalism. Bank Syariah Mandiri needs to make a clear and appropriate SOP to support the enactment of the ESOP in the future. It is also necessary to embrace relevant stakeholders to strengthen regulations so that the implementation of this program in the future creates benefits for all elements, Bank Syariah Mandiri as sharia banking itself, its employees as work units serving the public, the public as consumers, regulators, and other parties who are part of the stakeholders in this matter.

\section{Reciprocal ESOP on Employee Performance}

The ESOP program itself is beneficial for Islamic banking, the benefits of the ESOP itself include that employees contribute to the ownership of the company, a solution to overcome the crisis one day, and increase company productivity (Yunita, 2018), based on data that researchers find in the field because in Bank Syariah Mandiri itself has not yet implemented the ESOP program. This field data is still a mass perspective. 


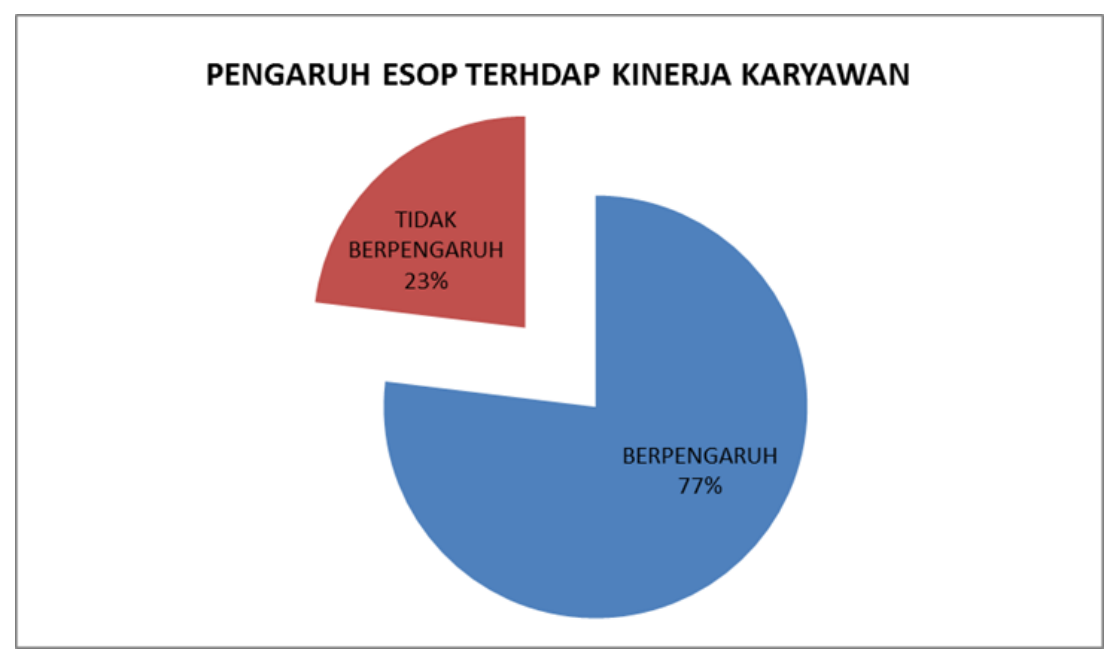

Figure 5. Effect of ESOP towards Employees' Performance Sources: Bank Syariah Mandiri 2019 Processed Data

The effect of ESOP on individual employee performance, the researchers found the majority of the answers from informants stated ten or equal to $77 \%$ of the total informants said they had an effect on employee performance, especially individual himself, three which is equivalent to $23 \%$ of all informants said there is no effect on individual performance. Relevant to the theory of expectation, the researchers' ESOP program suggests that the company is $77 \%$ optimistic that it can have implications for improving employee performance. When employees are given additional benefits in the form of company ownership, this theory assumes that employees will be motivated to improve their performance in order to achieve the desired grade promotion. It is important to have an ESOP influence on the individual employee performance that the informant conveyed in the interview in accordance with the intended use of the ESOP. The effect of ESOP on individual employee performance according to the informants, the researchers found the majority stated 10 out of 13 informants said it had a positive effect on employees' performance, especially themselves.

All things explained by this informant are also directly proportional to the theory of Vroom's (1964) explanation in Saktiyanto et al. (2013), which assumes that each individual believes that when the individual behaves in a particular manner, he will undoubtedly get certain things too. Special actions will get an exceptional result. That each outcome will, of course, be related to personal perceptions of how difficult it is to achieve an issue, then the effort will produce an achievement. That every result will be valuable, be an attraction for anyone, then everyone wants to create the expected value.

The relevance of the implementation of the ESOP program is the positive influence of the ESOP on employee performance at Bank Syariah Mandiri. The ESOP program is expected to have implications for improving employee performance. With 
the existence and implementation of this ESOP program, employee performance becomes special, meaning that employee has a strong sense of ownership of the company compared to the performance before the enactment of this program, employee performance is better than before, the employee becomes motivated and productive in the company because the employee in this case also has shares in the company, this is special behavior for the employee, with this ownership, the employee becomes active in their performance, want to develop their shares for the company.

The employee also realizes that many challenges and obstacles will be faced later. However, from here, he gets income no doubt he also considers a lot related to profit and loss, consideration of SOP, and the strength of regulation. It takes effort and process to produce the best achievement. To produce the best value, this ESOP needs to be prepared carefully, so it can go to the public and becomes an attraction for the employees themselves in investing in shares, and the public in putting their trust and reputation in Bank Syariah Mandiri.

As far as the findings of the researchers in the field interviews, the development of Bank Syariah Mandiri is considered quite good and significant from the increase in performance throughout 2016 to 2017 and continues to increase dramatically until now. The ratio of funding to the financing of Bank Syariah Mandiri so far ranges from $70 \%$ to $80 \%$, and it is still said to be safe in its capital position. Employee performance, according to information on a $B+$ scale, improves from the previous year, starting with discipline, achieving targets, synergizing coordination between employees, and public services.

Table 1

Employee Performance Questionnaire Results of PT Bank Syariah Mandiri Yogyakarta

\begin{tabular}{|c|c|c|c|c|c|c|}
\hline NO. & STATEMENT & STS & TS & $\mathbf{N}$ & $\mathbf{S}$ & SS \\
\hline 1. & Skilled at doing tasks according to the field of work & & & & 7 & 6 \\
\hline 2. & $\begin{array}{l}\text { Able to respond to specific tasks outside the main task and } \\
\text { develop creativity in solving problems related to the task }\end{array}$ & & & & 8 & 5 \\
\hline 3. & I obey the rules that apply in the company & & & 1 & 4 & 8 \\
\hline 4. & $\begin{array}{l}\text { Having the ability to establish good cooperation in a } \\
\text { team/colleague, for example, helping each other and willing to } \\
\text { accept the opinions of coworkers }\end{array}$ & & & & 5 & 8 \\
\hline 5. & $\begin{array}{l}\text { Responsibility for work behavior, basic tasks, work results, and } \\
\text { policies issued by the company }\end{array}$ & & & & & 7 \\
\hline
\end{tabular}

Source: Author Research Data

This is also strengthened by the questionnaire data that researchers made as supporting data in this study, from here researchers divided the questionnaire between a cross and random way to assess colleagues, superiors, or subordinates themselves regarding employee performance appraisal of Bank Syariah Mandiri so that the data is more objective. The results show that of 13 informants describing the good performance, with a skills rating scale of 6 SS (strongly agree) and $7 \mathrm{~S}$ (agree), response and creativity of 5 SS (strongly agree) and $8 \mathrm{~S}$ (agree), the loyalty of 8 SS 
(very agree), $4 \mathrm{~S}$ (agree) and $1 \mathrm{~N}$ (neutral), the cooperation of $8 \mathrm{SS}$ (strongly agree) and $5 \mathrm{~S}$ (agree), and finally, the responsibility of $7 \mathrm{SS}$ (strongly agree) and $6 \mathrm{~S}$ (agree), based on this indicator it is found that the scale assessment is quite good. But indeed, there needs to be a slight improvement in terms of the responsiveness of customer service and security responses because, based on the results of interviews, and also based on this questionnaire, the rating scale of response and creativity is minimal compared to other indicators.

In terms of employee productivity is in 50\% of the target, still lagging behind its parent bank, PT Bank Mandiri Tbk, with the achievement of employee productivity of $101.3 \%$ of the goal in 2018 (Tomo, 2018). Bank Syariah Mandiri needs to fix the governance of human resources, payroll, networks, and IT. There need to be more stringent and effective rewards and punishments for employees to have an effect on performance. So far, the researchers conclude that Bank Syariah Mandiri is still at a safe level in running the capital market, outside of the crisis factor going forward, because the crisis factor is sometimes unexpected and incidental. In this case, Bank Syariah Mandiri needs to observe the map of global micro and macroeconomic competition in order to face a monetary crisis such as in the future, so that capital market stability is maintained.

\section{The Patterns and Steps for Implementing ESOP as Alternative Strategies in Improving Employee Performance}

Many types of ESOP models can be applied as a form of improving employee performance, including the employee stock purchase program (Direct Employee Stock Purchase Plans). This pattern and strategy of buying shares do have weaknesses in terms of initial investment costs. Employees may be reluctant to see the amount of the initial deposit fee to open a security account that may not be suitable for the employee's pockets. The bank management must have a solution to this cost by adjusting the initial investment costs according to employee pockets, or the initial deposit fee is schematic, which does not burden employees in meeting their needs. However, it may cause a small share value, step by step, little by little, and it will become a promising investment stock value if it is processed and managed well, maximally, and accordingly. Through this form of adjustment, employees will voluntarily buy shares, and their performance in the company continues to run well.

Whereas if the bank wants to apply for stock grants, for the researchers themselves, this pattern can influence to improve the performance of employees in the company, because there is work competition between employees so that they are selected to get a bonus compensation. Bank management should continue to monitor the performance of employees so that the competition is conducive and healthy. The steps and patterns have been described which need to be taken by banks in making ESOP as an alternative to improving employee performance. 
First, banks need to strengthen the quality of corporate value so that banks can meet the requirements for an initial public offering and look beautiful and attractive to the public, strengthen the solidarity of all company members or create alliances, improve employee competency professionally and certify. Second, banks and regulators need to be involved in enhancing together existing regulations by revising these policies and regulations or making new policies and regulations that are more comprehensive. Third, banks need to make their own SOPs in accordance with company policies and employee welfare. Fourth, banks need to determine in advance the ESOP model that is in line with the company's environmental conditions. Finally, the bank starts operating the ESOP in its company, and in the process going forward continues to continuously evaluate this ESOP program onwards. These five steps and patterns are considered as alternative strategies for improving employee performance.

\section{CONCLUSION}

Based on the analysis, the researchers concluded that if the ESOP is applied at Bank Syariah Mandiri, the performance of the clerics will increase. The results showed that the ESOP program was, in fact, able to have implications for improving employee performance, meaning that employees have a strong sense of ownership of the company compared to if the employee does not have a stake in the company. Employees become motivated and productive in the company because the result performance will increase the value of shares that lead to the welfare of these employees. The strength of this research is that it provides an illustration that the ESOP has a model, objectives, patterns, methods, the involvement of internal and external parties of the company as well as separate and specific policy regulations in its application procedures, in order to implement the ESOP as a choice in sharing capital for companies wishing to carry out the policy in the middle of the company environment. This study also describes the analysis of research results and recommendations that are useful for Bank Syariah Mandiri, regulators, and readers.

Bank Syariah Mandiri needs to convince its employees both by making clear and appropriate SOP to support the enactment of the ESOP in the future, and provide as much information as possible about the world of capital markets, stock investments, especially ESOPs in all layers both top to bottom, also needs to improve the quality of its employees by holding qualifications and professionalization of employees so that employees can work in accordance with the full requirements and professionalism. Bank Syariah Mandiri needs to embrace relevant stakeholders to strengthen regulations so that the implementation of this program in the future creates benefits for all elements. For the Regulator, to jointly revise general regulations and policies as needed or to make the latest regulations and general policies more comprehensive. For the reader, it is informed about the ins and outs of ESOP in general, and the pattern of ESOP steps as an alternative to improve 
employee performance, so that the hope in subsequent studies can provide more detailed updates, especially related to the post-ESOP phenomenon in Islamic financial institutions.

\section{Limitation of The Study}

Weaknesses of this study include that this is still relative because it is taken from the views and perspectives of the masses, namely the Bank Syariah Mandiri, which is preparing an initial public offering and ESOP going forward and has not yet reached the stage of application and process. This research does not involve parties' regulatory makers that researchers can take advantage of in knowing and retrieving information about the current status of ESOP regulations.

\section{REFERENCES}

Anatan, L. (2010). Telaah Kritis Expectancy Theory Victor Harold Vroom. Jurnal Manajemen, 9, 19-30.

Asnaini. (2008). Pengembangan Mutu SDM Perbankan Syari' ah: Sebagai Upaya Pengembangan Ekonomi Islam. Jurnal Ekonomi Islam La Riba, 2(1), 35-49.

Bank Syariah Mandiri. (2018). Memperkuat Daya Saing Melalui Peningkatan Keunggulan Perusahaan. https://www.mandirisyariah.co.id/assets/pdf/annualreport/AR_2018_Mandiri_Syariah.pdf

Basri, A. F. M., \& Rivai, V. (2005). Performance Appraisal. PT Raja Grafindo Persada.

Brown, M., Minson, R., O'Connell, A., \& Ramsay, I. (2011). Why Do Employees Participate in Employee Share Ownership Plans? SSRN Electronic Journal. https://doi.org/10.2139/ssrn.1873802

Fitria, A. (2014). Beberapa Permasalahan Perbankan Syariah di Indonesia. https://badilag.mahkamahagung.go.id/artikel/publikasi/artikel/beberapapermasalahan-perbankan-syariah-di-indonesia-oleh-al-fitri-s-ag-s-h-m-h-i-5-11

Freeman, S. F. (2007). Effects of ESOP Adoption and Employee Ownership : Thirty years of Research and Experience Effects of ESOP Adoption and Employee Ownership : Thirty years of Research and Experience * Abstract : International Journal of Research in Management, Economics and Commerce, 14(4), 614-621.

Hartono, A., \& Wibowo, A. J. (2014). Pengaruh Employee Stock Ownership Program Terhadap Kinerja Perusahaan Publik Di Bursa Efek Indonesia. Modus, 26(1), 85. https://doi.org/10.24002/modus.v26i1.580

Hasanudin, H. M., \& Mubarok, H. J. (2012). Perkembangan akad musyarakah. Kencana Prenada Media Group.

Hull, R. M., \& Dawar, V. (2014). Agency theory, capital structure and firm performance: some Indian evidence. Managerial Finance.

Landau, I., Mitchell, R., O'Connell, A., \& Ramsay, I. (2007). Employee Share Ownership: A Review of the Literature. Employee Share Ownership Project, March.

https://scholar.google.fr/scholar?q=Employee+Share+Ownership\%3A+A+Review +of+the+Literature+landau\&btnG=\&hl=en\&as_sdt=0\%2C5\#1

Marietta, U., \& Sampurno, R. D. (2013). Analisis Pengaruh Cash Ratio, Return On Assets, Growth, Firm Size, Debt to Equity Ratio Terhadap Dividend Payout Ratio : 
(Studi Pada Perusahaan Manufaktur Yang Terdaftar di Bursa Efek Indonesia Tahun 2008-2011). Diponegoro Journal of Management, 2(3), 1-11. http://ejournal-s1.undip.ac.id/index.php/dbr

Moleong, L. J. (2017). Metodologi Penelitian Kualitatif. PT Remaja Rosda Karya.

Poerwandari, E. K. (2001). Pendekatan Kualitatif untuk Penelitian Perilaku Manusia. Lembaga Pengembangan Sarana Pengukuran dan Pendidikan Psikologi (LPSP3) Fakultas Psikologi Universitas Indonesia.

Purnawanto, B. (2010). Manajemen SDM Berbasis Proses: Pola Pikir Baru Mengelola SDM pada Era Knowledge Economy. Grasindo.

Ray, K. K. (2016). Employee Stock Option Plan and Firm Performance: a Quantile Regression Approach. Asian Journal of Empirical Research, 6(6), 152-166. https://doi.org/10.18488/journal.1007/2016.6.6/1007.6.152.166

Sabitah, N. M., \& Susilo, H. (2017). Implementasi Metode Penilaian Kinerja 360 Degree Feedback untuk Mengukur Soft Competence Karyawan (Studi pada PT Petrokimia Gresik). Jurnal Administrasi Bisnis S1 Universitas Brawijaya, 47(1), 56-61.

Saktiyanto, A. M. H., Wibowo, F. A., Purnamasari, F., Koostanto, H. B., Insan, H., Larasati, S., \& Syamriadi, Y. (2013). Expectancy teory (No. E-49).

Santosa, A. (2018). Saham Untuk Pekerja: Realisasi Demokrasi Ekonomi di Tempat Kerja. Universitas Mercubuana Yogyakarta. https://studylibid.com/doc/491875/saham-untuk-pekerja---universitas-mercubuana-yogyakarta

Saptarina, A., Budisantoso, S., Siswanto, H., Sulistyani, E., Hayati, H., Pramono, Y., Harjanti, A., Sungkana, Nyata, T., Muharto, Maiyo, A., Azhari, B., Rizanoordibyo, E., \& Herlambang, D. (2002). Studi tentang Penerapan ESOP Perusahaan Publik di Pasar Modal Indonesia. Badan Pengawas Pasar Modal, 1-103.

Setyaningrum, A. N. (2012). Pengaruh Employee Stock Ownership Program (ESOP) terhadap Kualitas Implementasi Corporate Governance \& Kinerja Perusahaan (Studi Kasus pada Perusahaan-Perusahaan yang Terdaftar di Bursa Efek Indonesia). Jurnal IImiah Mahasiswa FEB, 1(1).

Sugiyono. (2015). Statistika Untuk Penelitian. Alfabeta.

Tomo, H. E. S. (2018). Analisis penerapan konsep retail ready branch (rrb) pada pencapaian target dan kinerja pt bank mandiri (persero) tbk: kasus di cabang yogyakarta hygus eltana s $t$. Universitas Gadjah Mada.

Trébucq, S. (2004). THE EFFECTS OF ESOPS ON PERFORMANCE AND RISK: EVIDENCE FROM FRANCE. 1(4).

Vroom, V. H. (1964). Work and Motivation. Jossey-Bass.

Wiseman, R. M., Cuevas-Rodríguez, G., \& Gomez-Mejia, L. R. (2012). Towards a social theory of agency. Journal of management studies, 49(1), 202-222.

Yunita, N. A. (2018). Pengaruh Employee Stock Ownership (ESOP) terhadap Profitabiliras pada Perusahaan yang Terdaftar di Bursa Efek Indonesia. Jurnal $\begin{array}{llll}\text { Visioner } \quad \text { \& } \quad \text { Strategis, } & \text { 23-30. }\end{array}$ https://journal.unimal.ac.id/visi/article/view/313

Zhu, Z., Hoffmire, J., Hoffmire, J., \& Wang, F. (2013). Employee Stock Ownership Plans and Their Effect on Productivity: The Case of Huawei. International Journal of Business and Management Invention, 2(8), 17-22. www.ijbmi.org 